\title{
Survival analysis of patients with transplantation of keratinocytes in years 2008-2015.
}

Kitala D.1,2, Klama-Baryła A. 1,2, Łabuś W. ${ }^{1}$, Kraut M. 1, Glik J. 1,3, Nowak M. ${ }^{1}$, Kawecki M. 1,2

${ }^{1}$ Centre for Burn Treatment

2 Department of Health Sciences, Technical-Humanistic Academy

${ }^{3}$ Unit for Chronic Wound Treatment Organization, Division of Nursery, School of Health Care, Medical University of Silesia

\begin{tabular}{|c|c|c|c|}
\hline & CEA group & $\begin{array}{c}\text { All hospitalized } \\
\text { patients without CEA }\end{array}$ & Differences \\
\hline Age, years (mean $\pm S D)$ & $41.1 \pm 14.7$ & $45.3 \pm 16.9$ & $p>0.05$ \\
\hline $\begin{array}{l}\% \text { TBSA } \\
0-19 \% \\
20-39 \% \\
40-59 \% \\
60-79 \% \\
>80 \%\end{array}$ & $\begin{array}{l}12 \% \\
26 \% \\
31 \% \\
28 \% \\
2 \%\end{array}$ & $\begin{array}{c}60 \% \\
25 \% \\
9 \% \\
4 \% \\
2 \%\end{array}$ & $p<0.01$ \\
\hline $\begin{array}{l}\text { \% deep burns (III/IV) } \\
0-9 \% \\
10-19 \% \\
20-29 \% \\
30-39 \% \\
>40 \% \\
\end{array}$ & $\begin{array}{l}41 \% \\
23 \% \\
14 \% \\
16 \% \\
6 \% \\
\end{array}$ & $\begin{array}{l}37 \% \\
26 \% \\
12 \% \\
12 \% \\
13 \%\end{array}$ & $p>0.05$ \\
\hline $\begin{array}{l}\text { Days from admision to } \\
\text { main operation (mean } \pm \text { SD) }\end{array}$ & $37.0 \pm 20.7$ & $8.0 \pm 8.1$ & $p<0.01$ \\
\hline $\begin{array}{l}\text { Sex } \\
\text {-Female } \\
\text { - Male }\end{array}$ & $\begin{array}{l}14 \%(\mathrm{n}=11) \\
86 \%(\mathrm{n}=70)\end{array}$ & $\begin{array}{l}25 \%(\mathrm{n}=999) \\
75 \%(\mathrm{n}=2919)\end{array}$ & $\mathrm{p}=0.015$ \\
\hline Death & $\begin{array}{l}\text { Yes } 12 \%(\mathrm{n}=10) \\
\text { No } 88 \%(\mathrm{n}=71)\end{array}$ & $\begin{array}{r}\text { Yes } 14 \%(n=556) \\
\text { No } 86 \%(n=3362)\end{array}$ & $p>0.05$ \\
\hline Rehabilitation & $\begin{array}{l}\text { Yes } 27 \%(\mathrm{n}=22) \\
\text { No } 73 \%(\mathrm{n}=59) \\
\end{array}$ & $\begin{array}{l}\text { Yes } 14 \%(\mathrm{n}=542) \\
\text { No86\% }(\mathrm{n}=3376) \\
\end{array}$ & $\mathrm{p}=0.014$ \\
\hline $\begin{array}{l}\text { Total hospitalization lenght } \\
\text { in days (mean } \pm \text { SD) }\end{array}$ & $79.9 \pm 44.8$ & $26.5 \pm 25.3$ & $\mathrm{p}<0.01$ \\
\hline
\end{tabular}

\section{Differences in $40-79 \%$ TBSA group}

\begin{tabular}{|l|c|c|}
\hline & CEA group & Non-CEA group \\
\hline $\begin{array}{l}\text { Number of patients } \\
\text { with TBSA: }\end{array}$ & $\begin{array}{l}\mathbf{n}=\mathbf{2 5} \\
\mathbf{n}=\mathbf{2 3} \\
\mathbf{- 4 0 - 5 9 \%} \\
\begin{array}{l}-60-79 \% \\
\text { Total }\end{array}\end{array}$ & $\begin{array}{l}\mathbf{n}=\mathbf{2 5} \\
\mathbf{n}=\mathbf{2 3} \\
\mathbf{n}=\mathbf{4 8}\end{array}$ \\
\hline Age (years) & 38 & $\mathbf{4 1}$ \\
\hline $\begin{array}{l}\text { Days from admision to } \\
\text { main operation }\end{array}$ & 38 & 11 \\
\hline Hospitalization lenght & 82 & 38 \\
\hline Rehabilitation & 13 & 6 \\
\hline Death & $\mathrm{n}=7(14,6 \%)$ & $\mathrm{n}=23(48 \%)$ \\
\hline
\end{tabular}

\section{Goal}

Most advanced treatment of extensive burns is keratinocyte transplantation. It should however highlighted that results of clinical transplant keratinocytes are ambiguous. Limitations of this method include long waiting times for cell culture and its susceptibility to infection. The aim of this work was to verify the impact of the application of keratinocytes on the survival of patients. This study specify a group of patients with the greatest chance of successful of treatment and excluded patients in whom there is no reason to apply this costly treatment.

\section{Methodology}

All patients diagnosed with burns treated with cultured skin cells between 01.01.2008 and 01.01.2016 were included in the study. Assessment included: patient age and sex,\% TBSA,\% burns with a depth of III / IV, the number of days from admission to surgery and the need for rehabilitation. Cox proportional hazards model was used.

\section{Results}

The analysis included 81 patients with a diagnosis of thermal burns, who were treated with the use of autologous dermal cells. The obtained result of survival in this study is $88 \%$. The analysis shows that there is only one significant predictor of decease - the surface area of burn of third degree $(p=0.029$

\section{Discussion}

The purposefulness of conducting this expensive and timeconsuming procedure isn't clinically justified in groups of patients who may heal spontaneously (burn Ila). Qualification of patients under 50 years old for cell culture is associated with defining age as a negative prognostic factor and the impact of process of aging on the proliferative capacity of cells with normal morphology. 